S O W I N I E C

R. 29: 2018 , nr 52, s. $119-134$

https://doi.org/10.12797/Sowiniec.29.2018.52.06

\title{
MARZEC I MAJ 1968 WE WrocŁaWIU
}

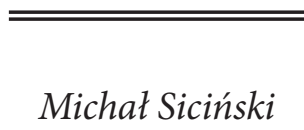

Michał Siciński

Wydarzenia polityczne mające miejsce w PRL w pierwszej połowie 1968 r., których głównym motywem były wystąpienia studenckie, znane są powszechnie jako „wydarzenia marcowe”, choć zaczęły się w istocie już w końcu stycznia 1968 warszawskimi manifestacjami związanymi z inscenizacją Mickiewiczowskich „Dziadów” w reżyserii Kazimierza Dejmka na scenie Teatru Narodowego, a zakończyły pierwszomajowym kontrpochodem we Wrocławiu (nie mam bliższych wiadomości na temat podobnych pierwszomajowych akcji w innych ośrodkach).

Ich główna odsłona rozpoczęła się wiecem na dziedzińcu Uniwersytetu Warszawskiego zwołanym w Dzień Kobiet i brutalnie rozpędzonym przez MO i tzw. aktyw robotniczy, po którym w następnych dniach wystąpienia studentów rozlały się po wszystkich ówczesnych większych ośrodkach akademickich i trwały z różnym natężeniem prawie do końca marca, znajdując pewne (choć na ogół niewielkie i słabo zorganizowane) poparcie także poza środowiskiem akademickim. Zarówno wkrótce po Marcu '68, jaki w ciągu następnych 50 lat opisywano i analizowano głównie przebieg wydarzeń marcowych w Warszawie, gdzie miały one najbardziej spektakularny przebieg, a także „wychowały” największą i najłatwiej rozpoznawalną grupę zasłużonych później, zwłaszcza w czasach KOR-u, pierwszej „Solidarności” i stanu wojennego, działaczy opozycji demokratycznej. Wielu z nich zdążyło jeszcze odegrać dużą rolę w przemianach ustrojowych 1989 r. i lat następnych, a niektórzy (np. Adam Michnik, Jadwiga Staniszkis) do dziś są w znaczący sposób obecni na polskiej i nawet międzynarodowej scenie 
politycznej. Pokolenie Marca '68 nadało szczególny koloryt polskim przemianom politycznym i kulturowym następnego półwiecza, zapewniając nieznaną w innych krajach komunistycznych i postkomunistycznych długotrwałą ciągłość tradycji wolnościowych i demokratycznych, jak również poczucie swego rodzaju więzi z tradycjami młodzieżowych rewolt 1968 r. na Zachodzie, zwłaszcza w RFN i we Francji, na przekór wszelkim odmiennościom ówczesnych warunków historycznych po dwóch stronach żelaznej kurtyny. To poczucie więzi oraz bliskości etosu byłych studenckich kontestatorów zachodnioeuropejskich (z których część, np. Joschka Fischer i Daniel Cohn-Bendit, była w 1989 r. i później już wpływowymi „dorosłymi” politykami) z ich polskimi kolegami było znaczącą politycznie wizytówką, którą Polska mogła się wykazywać (inną jest sprawą, czy potrafiła to skutecznie robić) w trudnym procesie powracania do Europy po upadku komunizmu.

Szczególna rola Warszawy w „legendzie” Marca '68 jest zrozumiała, niesie jednak ze sobą skłonność do niedoceniania roli innych ośrodków akademickich (może do pewnego stopnia z wyjątkiem Krakowa). Na PRL-owską "prowincję" rzadko wówczas docierali zachodni dziennikarze, a nawet polscy opozycyjni intelektualiści, skupieni zwłaszcza na Wydziale Filozoficznym Uniwersytetu Warszawskiego (Kołakowski, Brus, Bauman i inni), nie za bardzo się nią interesowali. Niesłusznie, bo mimo trudniejszych niż w stolicy warunków miała ona niemały „wolnościowy” potencjał, którego przykładem okazał się Uniwersytet Wrocławski (wówczas, i aż do 1989 r., noszący imię Bolesława Bieruta) i blisko współpracujące $\mathrm{z}$ nim podczas wydarzeń marcowych inne uczelnie Wrocławia. Młody wówczas (mniej niż 23-letni) jako uczelnia polska Uniwersytet Wrocławski, mimo swej nazwy, nie był - inaczej niż np. Uniwersytet Śląski w Katowicach - typową komunistyczną, „aparatczykowską" uczelnią opierającą się na prawomyślnej kadrze naukowej z tzw. awansu społecznego; posiadał sporą liczbę starej „,burżuazyjnej" profesury o lwowskim lub wileńskim rodowodzie (lub przynajmniej wychowanków takiej profesury z pierwszych lat powojennych), zaś w obszarze nauk społecznych - znaczącą liczbę wykładowców wywodzących się ze środowisk przedwojennej komunistycznej lub socjalistycznej inteligencji, często żydowskiego pochodzenia, gotowej poważnie traktować lewicową aksjologię wolności, równości i braterstwa, i skłonnej „trzymać za słowo” PRL-owską władzę na te wartości się powołującą. Niektórzy z nich, np. reformatorski profesor ekonomii Wincenty Styś, jedyny - o ile wiem - w dziejach PRL poseł wybrany (w 1957 r.) spoza „mandatowych” miejsc na listach wyborczych FJN, zresztą w znacznej mierze głosami wrocławskich studentów, odegrali znaczącą rolę w czasach tzw. polskiego Października. Wrocławianinem był wówczas także wybitny historyk 
i wybitny lewicowy opozycjonista Karol Modzelewski, współautor (wraz z Jackiem Kuroniem) słynnego „programu polskiej klasy robotniczej”, lecz on akurat siedział już w marcu 1968, nie pierwszy i nie ostatni raz w swym długim już życiu, w PRL-owskim więzieniu. Warto też może wspomnieć niezwykle popularnego wrocławskiego duszpasterza akademickiego z tych lat, ks. prałata Aleksandra Zienkiewicza - „Wujka”, obecnie oczekującego na rychłe wyniesienie na ołtarze.

Tacy ludzie jak oni przyczyniali się do kształtowania na uczelniach atmosfery „niepokorności” i krytycyzmu wobec poczynań władzy ludowej, do uwrażliwienia młodzieży na dziejące się nieprawości w duchu „socjalizm tak, wypaczenia nie"; nikt wówczas otwarcie nie kwestionował tzw. podstawowych zasad socjalizmu, lecz i prawie nikt nie wątpił, że „wypaczenia” bynajmniej nie skończyły się (jak głosiła ówczesna propaganda) w $1956 \mathrm{r}$.

Dalekie echa atmosfery żywego zaangażowania społecznego na ówczesnym Wydziale Matematyki, Fizyki i Chemii, gdzie studiowałem fizykę, słyszalne są do dziś: jego absolwentami z tych mniej więcej lat, w większości wypadków fizykami, są twórca i przywódca „Solidarności Walczącej” Kornel Morawiecki (ojciec premiera Mateusza Morawieckiego), Zygmunt Petru (ojciec Ryszarda Petru z Nowoczesnej), Ludwik Turko (przywódca KOD na Dolnym Śląsku po 2015 r.), o. Maciej Zięba (opozycjonista, później dwukrotny prowincjał zakonu dominikanów i bliski doradca Jana Pawła II), członkowie władz naziemnej i podziemnej „Solidarności” z lat 1980. Jan Waszkiewicz, Eugeniusz Szumiejko i Marek Muszyński, Aleksander Gleichgewicht z Solidarności Polsko-Czechosłowackiej, a później Norwesko-Polskiej, i wiele innych zasłużonych w późniejszych latach postaci. Jak widać, „,iskry” warszawskich wydarzeń z ósmego (i następnych dni) marca 1968 r. trafiły na Uniwersytecie Bolesława Bieruta, a zwłaszcza na moim ówczesnym wydziale, na podatny grunt.

Wrocław był jednak mimo wszystko „prowincją” i zadziałał z lekkim opóźnieniem w stosunku do Warszawy, a nawet Krakowa. Pierwszy ruch (narada, przygotowanie haseł) wykonali wieczorem 13 marca działacze Uniwersyteckiego Koła Turystycznego zebrani w lokalu ZSP w tzw. Wieży (Belwederze) w zabytkowym Gmachu Głównym Uniwersytetu. Pech (będący być może zasługą SB) chciał, że na tej pracy „nakrył” ich niespodziewanie jeden czołowych działaczy uczelnianej organizacji partyjnej. Turyści - a raczej organizatorzy turystyki studenckiej, w tych czasach bardzo masowej i będącej znaczącą formą dość swobodnej aktywności społeczno-kulturalnej, dającej możliwość pewnego wyżycia się różnym niespokojnym duchom - nie zrazili się tą wizytą, a nawet chyba pod jej wpływem postanowili przyspieszyć działania. Wizyta ta, niespodziewanie, okazała się korzystna w skutkach dla „wichrzycieli”, gdyż jednym z jej owoców był tekst „Kto 
inspiruje, kto przeszkadza”, wydrukowany nazajutrz w lokalnym tabloidzie (istniał już wtedy w PRL ten rodzaj gazet, choć nie był tak nazywany) „Wieczór Wrocławia”, komentowany potem przez studentów jako „donos już dawno gotowy i czekający tylko na wpisanie paru żydowskich nazwisk i imion”. W rzeczy samej zgęszczenie takich „nie całkiem słowiańskich” (jak się eufemistycznie wyraził jeden z mówców na rozpoczętym tegoż dnia wiecu okupacyjnym na uniwersytecie) nazwisk i imion było w tym krótkim tekściku uderzające i też mocno podkręciło nastroje, jednak w kierunku nie całkiem zgodnym $\mathrm{z}$ intencjami autora i redakcji. Nie skierowało bowiem oburzenia - a wręcz chwilami wściekłości - przeciwko „syjonistom”, ale przeciwko PZPR-owskim antysemitom.

Ówczesny Wrocław był znaczącym ośrodkiem życia żydowskiego. Czynna była, mimo hitlerowskich i powojennych dewastacji, synagoga Pod Białym Bocianem (po Marcu '68 i po wyjeździe wielu Żydów zamknięta, a gruntownie odnowiona i resakralizowana dopiero w latach 90. i na początku XXI w.), działał szeroko znany Teatr Żydowski (po 1968 r. przemianowany na Kameralny), były żydowskie szkoły, a prawie w każdym kiosku Ruchu można było nabyć „Fołks Sztyme” („Głos Ludu”, czasopismo w języku jidysz drukowane alfabetem hebrajskim). Jako chłopiec bawiłem się z żydowskimi dziećmi, kupowałem słodycze w sklepiku prowadzonym przez charakterystycznie brodatego Żyda, mój sąsiad (woźny w szkole, do której chodziłem, gdzie mój ojciec był kierownikiem, mama nauczycielką, a higienistką - pani Sara Margulis, być może jakaś kuzynka żony doktora Marka Edelmana z getta warszawskiego) pracował po godzinach „u Żyda”, tj. w fabryczce prefabrykatów plastykowych należącej do zabawnie żydłaczącego pana Abrahama Dresnera, będącego w komitywie z moimi rodzicami. W szkole i na studiach mieliśmy wiele koleżanek i kolegów (a także sporą liczbę wykładowców, na ogół cenionych i lubianych) o żydowskich nazwiskach i imionach oraz z charakterystycznym akcentem, kibicowaliśmy też gorąco Irenie Kirszensztein, później z męża Szewińskiej (w roku olimpiady w Tokio przeszedłem właśnie do klasy maturalnej), przez mych kolegów kibiców w oczywisty i najzupełniej naturalny sposób traktowanej jako Żydówka - choć w ówczesnej prasie sportowej trudno byłoby znaleźć wzmiankę o takiej treści. W szkole uczono nas szczegółowo o Holokauście, nie pomijano też tematu polskich szmalcowników. Żydzi i żydowskość nie były żadnym „problemem” - przeciwnie, był to swojski koloryt życia społecznego, postrzegany z reguły pozytywnie i przyjaźnie. Jakoś nie dostrzegaliśmy tej osławionej, ponurej „żydokomuny” w naszych elokwentnych wykładowcach filozofii marksistowskiej czy ekonomii politycznej socjalizmu (nie mówiąc już o profesorach matematyki czy fizyki) o „niesłowiańskich” nazwiskach, semickich rysach i często charakterystycznym akcencie; nutą niechęci do ustroju i do 
„robotniczo-chłopskiej” ideologii podszyty był już raczej nasz ironiczny stosunek do ich aryjskich kolegów z tzw. awansu społecznego, żywy zwłaszcza w czasach, gdy wprowadzono osławione „chłopskie punkty”, premiujące młodzież robotniczą i chłopską przy przyjmowaniu na studia. Nawiasem mówiąc, nie do końca rozumiałem wtedy znaczenie jednego z głównych źródeł ludowego antysemityzmu: klasowej zawiści wobec Żydów jako tych mądrzejszych, kulturalniejszych, lepiej wykształconych i z reguły, nawet w bardzo niesprzyjających warunkach, lepiej sobie radzących - bo religijne, ekonomiczne, polityczne i inne „uzasadnienia" antysemickich postaw są mimo wszystko chyba wtórne.

Jakkolwiek by nie było, antysemityzm był dla nas egzotyką; więcej, słyszeliśmy o nim w szkole i w domach jako o zjawisku haniebnym, ale dawno przezwyciężonym i już dawno (w Polsce przynajmniej) nieistniejącym. Pamiętaliśmy wprawdzie nagonkę przeciwko „syjonistycznemu agresorowi” z okresu wojny sześciodniowej z 1967 r., więc zaledwie dziewięć miesięcy wcześniejszego, ale mimo znamiennej, rzuconej wtedy przez Gomułkę uwagi na temat „syjonistycznych środowisk Żydów - obywateli polskich" traktowaliśmy ją jako należącą do dziedziny wymuszonej przez ZSRR polityki międzynarodowej, nieodnoszącej się do polskich Żydów. Tymczasem już zaraz po 8 marca 1968 r., gdy we Wrocławiu jeszcze nic szczególnego się nie działo, zabrzmiały w PZPR-owskiej propagandzie, w kontekście wydarzeń w Warszawie, tony „antysyjonizmu”, a pojęcie to, być może początkowo niejasne dla części robotników, dla wielu studentów od razu i w jasny sposób oznaczało antysemityzm. Nastąpił szok: to aż do tego doszło? Chcą prześladować naszych kolegów i naszych wykładowców, napuszczać nas na nich? Kto to robi? Dlaczego? Czy nie przeciwko temu protestują studenci w Warszawie i w innych miastach (choć naprawdę protesty zaczęły się od haseł obrony kultury narodowej i wolności słowa)? Czy nie trzeba ich poprzeć?

Gdy podczas zajęć laboratoryjnych przed południem 14 marca paru kolegów (czy może nawet tylko jeden, nie pamiętam tego dokładnie) zaczęło mówić o konieczności poparcia studentów warszawskich, zaprotestowania przeciwko brutalności MO, o wolności słowa i rzecz jasna o antysemityzmie, odzew był niesamowity: cały (naprawdę cały!) kilkudziesięcioosobowy rocznik ruszył podczas przerwy obiadowej ku gmachowi głównemu uniwersytetu (Instytut Fizyki znajdował się kilkaset metrów dalej, po drugiej stronie Odry, przy ówczesnym placu Dąbrowszczaków a dzisiejszym Maxa Borna - na cześć wielkiego fizyka niemieckiego, który tam pracował przed wojną) i zameldował się przed najbardziej reprezentacyjną salą uczelni - Aulą Leopoldina. Przed aulą, bo ona sama była już szczelnie wypełniona przez młodzież i przez kadrę nauczającą. Był rektor, wybitny geograf prof. Alfred Jahn, lwowiak, bezpartyjny, bardzo szanowany przez młodzież. 
Był dziekan mojego wydziału, fizyk prof. Rzewuski, i wielu znanych profesorów. Przemawiali studenci i studentki, mówili o proteście przeciwko działaniom władz i o potrzebie ogłoszenia wiecu okupacyjnego (takie określenie zostało wówczas ukute, widać słowo „strajk” nie wydawało się najlepsze). Aż w pewnej chwili ktoś przedarł się na mównicę z egzemplarzem świeżo dostarczonego do kiosków „Wieczoru Wrocławia” i zaczął głośno czytać tekst „Kto inspiruje, kto przeszkadza?” z żydowskimi nazwiskami „wichrzycieli”.

Aula zawrzała. „Antysemityzm!”, „hańba!”, „faszyści!” krzyczano. Zapowiedziano wystąpienie rektora. Profesor Jahn spokojnym, stanowczym głosem powiedział, że rozumie oburzenie młodzieży i że będąc suwerenną władzą na terenie uczelni, przyjmuje do wiadomości rozpoczęcie wiecu okupacyjnego. Że mocą jego decyzji wiec jest legalny i że ufa studentom, gdy chodzi o zapewnienie mu zorganizowanej formy, a także zakończenie go w odpowiednim czasie i okolicznościach (o ile pamiętam, mówiono wówczas o wiecu 24-godzinnym, ale w tym wystąpieniu prof. Jahna żaden konkretny termin nie padł). Odpowiedziały mu burzliwe oklaski.

Ukonstytuował się komitet wiecowy, w składzie którego było wielu działaczy uczelnianego ZSP. Zorganizowano straż studencką, dość sprawnie pilnującą porządku (co nie było oczywistością w warunkach paru tysięcy osób stłoczonych teraz w gmachu głównym uniwersytetu), dokładnie kontrolującą wchodzących do budynku i konfiskującą alkohol (były to zresztą zupełnie odosobnione przypadki, co mogłoby dziwić wobec powszechnie znanego nieszczególnego zamiłowania młodzieży studenckiej do abstynencji, lecz w tej konkretnej sytuacji, wśród nastrojów „wolnościowego uniesienia”, było w pełni zrozumiałe). Z czasem, z pomocą administracji uczelnianej, zadbano o aprowizację, w czym wkrótce wydatnie dopomogła „okoliczna ludność”, na wyścigi znosząca żywość i napoje (bezalkoholowe) dla „naszych ukochanych studentów”. Rzecz jasna musiała ona zostawiać te dary w bramach uczelni, poza które nikogo prócz studentów i pracowników uczelni straż wiecowa nie wpuszczała. Bardzo szybko się bowiem rozniosło, że na uniwersytecie, a wkrótce i na innych uczelniach, dzieje się „coś bardzo ważnego" - choć pewnie początkowo niełatwo było powiedzieć, co mianowicie: moja 60-letnia wówczas matka, nauczycielka szkoły podstawowej mająca ukończone tylko przedwojenne tzw. seminarium nauczycielskie (odpowiednik powojennego liceum pedagogicznego), mówiłam mi potem, iż zaraz się domyśliła, że dzieje się „to, co w Warszawie”, i że - jak wówczas uważała - na pewno powinienem tam być.

A działo się ciekawie. Przede wszystkim zaczęły wkrótce przybywać delegacje $\mathrm{z}$ innych uczelni wrocławskich, w pierwszej kolejności (o ile pamiętam) z politechniki, z wiadomościami o rozpoczęciu tam wieców okupacyjnych podobnych 
do naszego. Trudno mi dziś powiedzieć, jakie wiece te miały rozmiary i jak przebiegały, ale $\mathrm{z}$ wielką radością witaliśmy rozszerzanie się protestu, w tym i to, że - wedle słów delegatów - wszędzie były one zalegalizowane przez rektorów (później ci rektorzy, którzy prawdopodobnie podjęli taką decyzję w chwili dezorientacji i pod presją autorytetu rektora Jahna, po zaostrzeniu się sytuacji z niej się wycofali i prof. Jahn został sam, lecz na razie euforia była powszechna i rósł mit jedności całego środowiska akademickiego). Koledzy wysyłani w różnych sprawach poza Gmach Główny informowali, że zajęcia dydaktyczne we wszystkich innych (kilkunastu wówczas) budynkach uniwersyteckich przestały się odbywać i że „społeczeństwo nas popiera” - to stwierdzenie było w tak ogólnej i jednoznacznej formie na pewno przesadą, lecz jakieś empiryczne podstawy miało. Pojawiły się doniesienia o zatrzymywaniu przez SB, na zewnątrz budynków uczelnianych, pojedynczych studentów biorących udział lub podejrzanych o branie udziału w proteście. Były to wieści elektryzujące, bo przecież o działalności tajnej policji niczego jeszcze wtedy z własnych doświadczeń nie wiedzieliśmy, a po nie tak dawnych wówczas czasach stalinowskich pozostała ponura legenda okrutnej i zbrodniczej „bezpieki”; o dziwo jednak zatrzymanych (tych, o których się dowiadywaliśmy) wkrótce zwalniano (dłuższe aresztowania, w tym dotyczące „wichrzycieli” z zebrania na Wieży z 13 marca, zaczęły się nieco później), a pytania zadawane im przez esbeków dotyczyły bodaj wyłącznie kwestii antysemityzmu: „Czy na pewno chodzi wam o tych Żydów” lub tp. Wewnątrz ogromnego, zabytkowego Gmachu Głównego uniwersytetu trwało niezwykle ożywione wiecowanie, pospieszne lektury ( $w$ tym na temat stalinizmu, socjalizmu, i antysemityzmu właśnie), zacięte dyskusje (głównie skupione wokół pytania „co dalej?”) oraz, w ich efekcie, uchwalanie rezolucji i postulatów (które to słowo, w tego rodzaju kontekście politycznym, bynajmniej nie jest wynalazkiem Sierpnia '80 tyle że w Marcu '68 nie miało szans na tak szerokie rozpropagowanie). Ich ton był podniosły, a frazeologia właściwa epoce: „my, córki i synowie robotników i chłopów...”, „niezłomnie pozostając na gruncie socjalizmu...” itp., a dalej „wyrażamy solidarność... (też słowo bynajmniej niewynalezione politycznie w 1980 ani nawet w 1977 r.), ,protestujemy przeciwko łamaniu konstytucyjnej zasady wolności słowa...”, „przeciwko aresztowaniom...”, „akcjom Milicji Obywatelskiej...”, „W obronie kultury narodowej...”, „żądamy poszanowania autonomii uczelni...”, „żądamy prawdy w środkach masowego przekazu...” itd. Było też rzecz jasna, choć w trochę pokrętnej formie, o antysemityzmie. Było tego wszystkiego dużo, i prawie „dla każdego coś miłego”. Z dzisiejszej perspektywy może jednak dziwić zupełny brak odniesień do spraw tzw. bazy społeczno-ekonomicznej, w tym do materialnych warunków życia społeczeństwa (dość przecież wówczas 
ciężkich), a także do sytuacji międzynarodowej, choćby w kontekście „bratnich” protestów studenckich zaczynających się już właśnie w wielu krajach, co mimo informacyjnych blokad nie było dla nas tajemnicą - a przecież w odległej o $80 \mathrm{~km}$ od Wrocławia Czechosłowacji trwała już wtedy Praska Wiosna, której preludium stanowiły wystąpienia studentów; zresztą czescy studenci byli (podobno, bo ja ich nie widziałem, siedziałem przecież cały czas na uniwersytecie) w Marcu na Politechnice Wrocławskiej z wyrazami solidarności i przekazem typu „widzicie, a u nas się już udało, trzymajcie się”. Zwłaszcza „wyniosłe” zignorowanie kwestii dotykających i obchodzących robotników musieliśmy już wkrótce (nawet jeszcze przed końcem wydarzeń marcowych) uznać za duży błąd, który też część marcowych aktywistów próbowała poniewczasie naprawić. Bądźmy jednak szczerzy nastroje w Auli Leopoldina 14 marca 1968 i w dniach następnych nie były tego rodzaju, by wypadało tam myśleć i mówić np. o zaopatrzeniu sklepów (lub choćby o jakości obiadów w stołówkach studenckich).

Gdy dyskutowali i układali swe rezolucje studenci, nie próżnowali też ich profesorowie. Rada Wydziału Matematyki, Fizyki i Chemii, pod kierownictwem dziekana Rzewuskiego, zebrała się, by uchwalić „bezprecedensową” (jak później to określały czynniki partyjne) rezolucję popierającą postulaty studenckie. Po przeszło 50 latach nie jestem w stanie odtworzyć jej dokładnej treści ani też ocenić, jak mała się ona do uchwały Rady Wydziału Filozoficznego Uniwersytetu Warszawskiego (z Kołakowskim, Brusem i innymi), która wywołała wściekłość władz politycznych i stała się przyczyną czy też pretekstem do rozwiązania tego wydziału i do wyrzucenia, decyzją ówczesnego ministra szkolnictwa wyższego Henryka Jabłońskiego (późniejszego przewodniczącego Rady Państwa), zresztą od strony formalnej całkowicie bezprawną, najwybitniejszych jego profesorów. Na gruncie wrocławskim, i w ogólności „na prowincji”, tj. poza Warszawą, był to jednak z pewnością ewenement - szkoda, że nie dość wówczas, jak i do dziś, zauważony i odnotowany przez historyków. Co do rezolucji studenckich, to prócz haseł dotyczących wolności słowa, obrony kultury narodowej (głównie w kontekście „Dziadów” Dejmka), żądań uwolnienia aresztowanych i protestów przeciwko antysemityzmowi ważnym ich wątkiem było żądanie rzetelnej informacji i zaprzestania propagandowych kłamstw; hasło „prasa kłamie!” stało się zresztą wkrótce jednym z najbardziej nośnych haseł wiecowych, zwłaszcza w miarę napływania kolejnych numerów gazet pełnych wyrazów oburzenia na „wichrzycieli” i na „elementy antysocjalistyczne” (zwane też „nieodpowiedzialnymi elementami”) i wysłuchiwania przez studentów kolejnych, podobnych w swej tonacji wiadomości radiowych (telewizji wtedy w pomieszczeniach dostępnych dla wiecujących jeszcze nie było). Ze względów bezpieczeństwa przeciwpożarowego nie 
paliliśmy gazet, postanowiliśmy natomiast nie tylko umieścić nasze postulaty na ulotkach przeznaczonych do skierowania „na miasto”, ale z głupia frant przekazać je do redakcji wrocławskich organów prasowych (prócz wspomnianego już, niezbyt na ogół poważnie traktowanego „Wieczoru Wrocławia” istniały wtedy dwa: „Gazeta Robotnicza”, nawiązująca swym tytułem do socjalistycznego pisma wydawanego po polsku we Wrocławiu jeszcze przed I wojną światową, oraz „Słowo Polskie", mające kontynuować tradycję pierwszej gazety polskiej wydawanej $\mathrm{w}$ tym mieście zaraz po II wojnie) $\mathrm{z}$ żądaniem opublikowania ich, i to w ciągu 48 godzin, pod groźbą kontynuowania wiecu okupacyjnego i podjęcia „dalszych niezbędnych w tej sytuacji działań" (czy czegoś podobnego, nie pamiętam już dokładnych sformułowań)!

Jak na głęboką, późnogomułkowską komunę i na zaledwie parę tysięcy młodych ludzi stłoczonych na jednym, i to raczej prowincjonalnym uniwersytecie był to wyraz dość ułańskiej fantazji. A jednak postulaty wydrukowano, i to przed upływem 48 godzin! Rzecz jasna $\mathrm{z}$ „odpowiednim” komentarzem, ale wydrukowano. Uznaliśmy to za nasz duży sukces, choć można na to patrzeć także jako na chytry krok władz zmierzający do rozładowania napięcia i wygaszenia protestów; jedno nie wyklucza zresztą drugiego. Ja sam, z perspektywy ponad 50 lat i doświadczeń Grudnia '70, Czerwca '76, Sierpnia '80 i Grudnia '81, stanowczo uważam to wydarzenie za na pewno ograniczony, ale jednak sukces: społeczeństwo dowiedziało się (w skali większej, niż możliwe to było z ulotek, z Wolnej Europy i z tzw. szeptanki) o naszych celach i intencjach, otrzymało informację, że jednak „da się coś zrobić”, oraz zachętę do działania (inną jest sprawą, czy z tej zachęty skorzystało); studenci uzyskali satysfakcję, że „coś się udało”, i pokaźny impuls mobilizacyjny (rozchodziliśmy się pełni ambitnych planów dalszych działań), który miał zaprocentować po latach, a wiec okupacyjny, jeśli nie zostałby pokojowo i „w zwartym szyku” zakończony demokratyczną decyzją samych wiecujących, zostałby albo rozbity siłowo, albo po kilku-kilkunastu dniach sam rozszedłby się po kościach, czego chyba za sukces nie dałoby się uznać. Śmiem nawet twierdzić, że taka formuła protestu - dla której alternatywą było wyjście na ulice (do czego niektórzy nawoływali) i nieuniknione starcie z MO i ZOMO lub ORMO „Zwieńczone” bardzo prawdopodobną masakrą i masowymi represjami i taka forma jego zakończenia czy też zawieszenia, do jakiej doszło 16 marca, była - toutes proportions gardées - preformacją robotniczych strajków sierpniowych z 1980 r. Nie miała wprawdzie dalszego ciągu takiego jak powstanie „Solidarności" i, w dalszej perspektywie, przemiany ustrojowe z 1989 r., ale pamiętajmy: nie chodziło wtedy o klasę robotniczą, a "tylko" o studentów (a studiowało w tych czasach nie więcej niż 5-6\% młodzieży w tym wieku, nie 50\% jak obecnie), i nie 
o łagodnego i ustępliwego Gierka, ale o dogmatycznego Gomułkę, który nie wahał się dwa i pół roku później rozstrzelać robotniczych protestów na Wybrzeżu. Nadto, nie było jeszcze wtedy KOR-u, nie było też jasno sformułowanego programu samoorganizacji i cywilnej samoobrony społecznej.

Żądanie opublikowania w „reżimowej” prasie postulatów studenckich, a także same postulaty, miały w wiecowej atmosferze wymiar nie tylko polityczny, ale i rozrywkowo-artystyczny: znalazły wyraz w licznych naprędce układanych żartach i piosenkach, z których jedną warto może przytoczyć w całości:

Prawdy dajcie nam żakom, nam żakom,

Nam i wszystkim Polakom, Polakom,

Gdy jej w prasie nie będzie, nie będzie,

Wiec przedłużyć trza będzie, trza będzie.

Wy nam oczy mydlicie, mydlicie,

Od mydlenia aż pieką, aż pieką,

Precz z gazami, pałami, pałami,

Precz z Moczara bezpieką, bezpieką.

My w stołówce żywieni, żywieni,

Demokracji spragnieni, spragnieni,

Cała Polska jest $\mathrm{z}$ nami, jest $\mathrm{z}$ nami,

Nie zrobicie nic sami, nic sami.

Ostatnie dwa wersy wyrażały zbytni chyba optymizm, lecz takie były w tych dniach nastoje i nadzieje. Inne przyśpiewki i wierszyki mówiły rzecz jasna o „Dziadach” i o Mickiewiczu („Biedak w grobie się przewraca, że na darmo jego praca, sława wisi już na włosku, jakoś strasznie po Dziadowsku” lub też „Nowosilcow w ciemnym grobie, może spać spokojnie sobie, zastępują go w robocie pewnych towarzyszy krocie”), o wolności słowa, no i o Żydach. Taka masowa, paraartysyczna twórczość zapewniała odprężenie w chwilach między dyskusjami polityczno-ideologicznymi, „niezależnymi wykładami” (tego pojęcia też nie wymyślono dopiero w czasach Uniwersytetu Latającego z końca lat 70., było ono już zresztą użyte pod zaborami, na początku XX w.), mowami „przywódców” (niestety, o ile wiem, żaden ani żadna z nich nie utrzymali się, w zauważalny społecznie sposób, w takiej roli po zakończeniu wiecu), powitaniami delegacji z innych uczelni, uroczystym śpiewaniem Międzynarodówki (tak, tak, takie były czasy) na przemian $\mathrm{z}$ hymnem państwowym i, słuchanymi $\mathrm{z}$ wielką uwagą i napięciem, wystąpieniami rektora. Rektor Jahn był prawie stale obecny na wiecu (choć, jak się później dowiedzieliśmy, wyjeżdżał na jakieś rozmowy polityczne), starał się 
tonować nastroje i wzywał do zachowania spokoju - choć spokój i tak był nadspodziewany, nawet wtedy, gdy drugiego dnia wiecu uniwersytet otoczyły siły policyjne (nie wiem, czy było to ZOMO, czy „tylko” ORMO, nie rozróżnialiśmy tego wówczas zbyt dokładnie), a straż wiecowa zaryglowała bramy i trzeba było liczyć się ze szturmem - do którego jednak, zapewne nie bez wpływu negocjacyjnych wysiłków rektora, w końcu nie doszło. Kilkakrotnie zapewnił, że wiec pozostanie legalny bez względu na okoliczności, i słowa dotrzymał, również wtedy, gdy pozostał pod tym względem sam wśród rektorów ośmiu wrocławskich wyższych uczelni (nie wiem, na których z nich - prócz politechniki - udało się realnie zorganizować wiece okupacyjne, a które tylko „nadrabiały miną”). Oswajał studentów, w tym komitet wiecowy, z myślą o konieczności „honorowego" i pokojowego zakończenia wiecu (do czego też trzeciego dnia doszło - po spełnieniu przez prasę, a w istocie przez władze polityczne, warunku opublikowania naszej rezolucji); nie jest natomiast prawdą, że „żądał” albo „nakazywał” opuścić budynek uczelni, o co później niektórzy go pomawiali, sugerując nawet, iż to on, z poduszczenia władz partyjnych, w istocie spacyfikował młodzież i zmarnował jej zapał. Przemawiał z wielką powagą i odpowiedzialnością za słowo, ściśniętym zwykle głosem, a uśmiechnął się bodaj tylko raz, gdy na egzaltowany nieco okrzyk jednej ze studentek „więcej takich ludzi dla Polski!” odpowiedział „kochani, nie róbcie tu ze mnie bohatera, bo ani wam, ani mnie nie wyjdzie to na dobre!".

Postawa reszty profesury i niższych pracowników naukowych, dość licznie obecnych na wiecu, była mniej jednoznaczna. Dziekani i rady innych wydziałów jakoś nie poszli w ślady Mat.-Fiz.-Chem. i nie poparły otwarcie studentów, czemu trudno się było dziwić, znając skład społeczny i poziom upartyjnienia kadry tych wydziałów, wśród których niechlubną czołówkę stanowił Wydział Prawa i Administracji. Część przedostających się na mównicę profesorów straszyła, próbowała nawoływać studentów do rozejścia się i do powrotu do normalnych zajęć uczelnianych (choć takowe, o ile wiem, w ogóle się w czasie wiecu okupacyjnego nie odbywały). Jedna z wykładowczyń z mojego wydziału, nieco spanikowana, próbowała nawet zorganizować „Zwykły” wykład z fizyki jądra atomowego na ogromnej sali Balzera, gdzie wiecowano; argumentowała, iż „jednym z zarzutów przeciwko nam (tzn. protestującej młodzieży) może być to, że się nie uczymy, odsuńmy więc od siebie ten zarzut". Odpowiedział na to jeden ze studentów, zwracając się do sali: „czy chcecie jutro przeczytać w gazetach, że zajęcia na uniwersytecie odbywają się normalnie?”. Do wykładu z fizyki jądra oczywiście nie doszło. Ogólnie jednak kadra naukowa - rzecz jasna ta jej część, która na wiecu okupacyjnym była, bo bardziej prawomyślni i wystraszeni się pochowali - zachowała się „na poziomie” i pozostawiła dobre wspomnienia o swojej postawie. 
Nie było w każdym razie mowy o jawnym jej udziale w pacyfikowaniu młodzieży ani w późniejszych represjach, co bardzo korzystnie odróżniło Uniwersytet Wrocławski od wielu polskich uczelni, w tym od krakowskiej AGH, gdzie osiem lat później znalazłem zatrudnienie i gdzie wkrótce, we współpracy ze studentami ówczesnego Wydziału Elektrycznego, związałem się na szereg lat z opozycją demokratyczną. Nie wątpiłem już wtedy, że doświadczenia Marca '68 oraz ruchów studenckich w innych krajach (o których 10 lat po Marcu miałem możliwość długo rozmawiać z przywódcą zrewoltowanej młodzieży zachodnioniemieckiej z lat 1967-68, Rudim Dutschkem) mogą się jeszcze nieraz przydać. Było więc naturalne, że po strajku studenckim na AGH w lutym 1981 r., organizowanym już w zupełnie innych czasach i warunkach niż Marzec '68, wystąpiłem z inicjatywą upamiętnienia Marca kamienną tablicą wmurowaną w jeden $\mathrm{z}$ budynków uczelni. Byłem dziwnie przekonany, że taki „punkt orientacyjny” jeszcze się w przyszłości przyda - i rzeczywiście, już po 13 grudnia 1981 zaczął się wielokrotnie przydawać jako punkt zborny kolejnych protestów społecznych i ich kolejnych upamiętnień (w tym strajku protestacyjnego na AGH przeciwko stanowi wojennemu, brutalnie stłumionego przez ZOMO). Tablica do dziś jest na swoim miejscu i czeka na swe kolejne „zastosowania” - oby mniej dramatyczne niż kiedyś.

Decyzja o zakończeniu wiecu okupacyjnego na Uniwersytecie im. Bolesława Bieruta we Wrocławiu dojrzewała stopniowo, lecz największy wpływ na nią miało ogłoszenie wiecującym, 17 marca przed południem, iż spełnione zostało żądanie opublikowania $\mathrm{w}$ prasie postulatów studenckich. Była prawie jednomyślna, zaś samo rozchodzenie się wiecujących, uprzątanie opuszczanych pomieszczeń uniwersyteckich itd. - dobrze zorganizowane. W wystąpieniach towarzyszących tej decyzji członkowie komitetu wiecowego podkreślali, że odniesiono sukces: „tylko we Wrocławiu nie doszło do starć z milicją, tylko w naszym mieście społeczeństwo ma wiedzę o naszej akcji, popiera nas, nie daje się oszukać; tylko my rozchodzimy się w zorganizowany sposób i przechodzimy do innych form działania”. Mogło to wyglądać na robienie dobrej miny do złej gry, ale faktem jest, że we Wrocławiu znacznie mniej niż gdzie indziej słychać było o organizowanych przez partię masówkach z okrzykami „literaci do pióra, studenci do nauki!”, „syjoniści do Izraela!" (albo do Syjonu, co prosty lud wymawiał czasem jako do „Syjamu”, tzn. do kraju dziś znanego jako Tajlandia), „wichrzycielom połamiemy kości!” itp. Nikt też z moich kolegów ani moich profesorów Żydów nie wyjechał (choć może nie o wszystkich wiedziałem), a Wydziałowi Mat.-Fiz.-Chem., inaczej niż Wydziałowi Filozoficznemu na Uniwersytecie Warszawskim, nic się nie stało: 
nawet nikogo nie zwolniono, przynajmniej od razu (choć parę osób się przestraszyło i zapisało do PZPR, w tym mój przyszły promotor). Nie oznacza to wcale, że poczucie sukcesu było powszechne albo pełne: przeciwnie, powszechne było poczucie zawodu po tym, jak opuściwszy wiec z wielkimi nadziejami na dalsze działanie, widzieliśmy w następnych dniach „opadanie fali rewolucyjnej” (taka leninowska frazeologia była wówczas w użyciu), zniechęcenie, a i coraz więcej niezrozumienia ze strony tzw. społeczeństwa.

Nie wszyscy się temu poddawali. Były próby, choć zdaje się, że dość anemiczne, akcji ulotkowych w zakładach pracy (jeden z moich kolegów, Żyd zresztą, trafił w związku z tym do aresztu), próby - nieskoordynowane - bojkotowania zajęć uczelnianych (nawet na tak „niepolitycznej” uczelni jak ówczesna WSWF), była próba (o której jeszcze wspomnę) niezależnego pochodu pierwszomajowego. Zapału i nadziei było, co do przeciętnej, dużo więcej niż 8-10 lat później, gdy kiełkowała opozycja demokratyczna, w tym niezależny ruch studencki. Brakło jednak myśli organizacyjnej i programowej, no i okoliczności polityczne mniej sprzyjały. Brzmi to może jak banał, ale pokolenie Marca musiało jeszcze trochę poczekać na swój czas.

W ciągu kwietnia nic widocznego nie działo się na polskich uczelniach: najaktywniejsi siedzieli w więzieniach (pod tym względem Wrocław, gdzie aresztowań było na razie bodaj tylko kilka, był pozytywnym wyjątkiem), inni się przestraszyli albo „zwątpili”, a największa chyba liczba nie wiedziała, co konkretnie dalej robić; nie dopracowano się jeszcze wtedy tej formy niezbyt spektakularnej, ale pozwalającej znacznej liczbie osób na stałe „czymś (opozycyjnym) się zając””, budując przy okazji więzi organizacyjne, jaką od powstania KOR-u było wydawanie niezależnej prasy i publikacji. Gdy skończyły się wiece, ogromna większość rozbudzonej politycznie młodzieży niecierpliwie czekała na polecenia i instrukcje na temat „dalszej pracy”, a gdy te nie nadchodziły - bo i nie miały skąd wkrótce się zniechęcała. Ci nieliczni, którzy nie chcieli się zniechęcić, wyglądali okazji, by „mimo wszystko coś zrobić”.

Półtora miesiąca po wiecach okupacyjnych jedną z takich okazji stał się hucznie i bardzo urzędowo świętowany w PRL 1 maja. Do oficjalnego pochodu, w którym maszerowali głównie robotnicy i reszta dorosłego „ludu pracującego miast i wsi”, wmieszała się grupa studentów, głównie z Politechniki Wrocławskiej. Późniejsze oficjalne dane, zapewne jak zwykle zaniżone, mówiły o ok. 200 osobach; jeśli więc nawet nie było tych śmiałków więcej, to i tak jak na ten czas, w którym uczelnie w całym kraju wydawały się dość już gruntownie spacyfikowane, a zniechęcenie było powszechne, była to spora liczba. Studenci znienacka rozwinęli transparenty z opozycyjnymi treściami przed trybuną honorową, potem po przejściu przed nią 
zawrócili i przeszli jeszcze raz, wznosząc też stosowne okrzyki. Liczyli (sprawę znam z relacji jednego z uczestników kontrpochodu, mojego późniejszego kolegi na studiach filozoficznych na uniwersytecie) na przyłączenie się do nich uczestników oficjalnego pochodu, co rzecz jasna w żadnych zauważalnych rozmiarach nie nastąpiło. Obyło się zatem bez większej „zadymy” z udziałem milicji, SB sfilmowała natomiast starannie większość „,wichrzycieli”, którzy nie wpadli jakoś na pomysł, by np. założyć kominiarki, w następstwie czego, po zidentyfikowaniu, wielu z nich (a może i wszyscy, nie wiem tego dokładnie) zostało wyrzuconych z uczelni, a część powołana do wojska. Na studia powrócić mogli - tak przynajmniej było z moim wspomnianym kolegą - po dłuższym okresie pracy fizycznej. Tego rodzaju „wychowywanie przez pracę" było w tych czasach w modzie u władz komunistycznych, jedną z odpowiedzi na wydarzenia marcowe było wprowadzenie na studiach obowiązkowych tzw. praktyk robotniczych, tj. okresów (na szczęście krótkich) pracy fizycznej o charakterze niezwiązanym z kierunkiem studiów, a ponadto obowiązkowych przez, teoretycznie, prawie cały czas studiów, tzw. lektoratów z nauk politycznych - typowej politgramoty mającej „uświadamiać" młodzież, szybko nazwanej przez studentów „lekcjami religii” (analogicznie do „procesji”, jak nazywano oficjalne pochody pierwszomajowe). Na mojej uczelni lektoraty z „religii” szybko się zresztą jakoś rozeszły po kościach, a jako resztówka $\mathrm{z}$ nich pozostały zwykłe wykłady z politologii, już tylko na jednym roku studiów. Osiągnęly one zresztą z czasem całkiem przyzwoity poziom, a kierunek ich oddziaływania ideologicznego był, jak łatwo się domyślić, niekoniecznie zgodny z oczekiwaniami władz. Stan taki trwał w zasadzie do czasów pierwszej „Solidarności” i do strajków studenckich ze stycznia-lutego 1981 r., w następstwie których, i w zgodzie z duchem czasu, wprowadzono obieralność przedmiotów „ideologicznych", teraz już nazywanych raczej humanistyczno-społecznymi, w tym filozofii marksistowskiej i właśnie nauk politycznych.

Ten 1 maja był już ostatnim znanym mi akordem Marca '68, po którym nastąpiła długa cisza, choć były jeszcze próby jakichś akcji protestacyjnych przeciwko sierpniowej inwazji na Czechosłowację; było to jednak w czasie studenckich wakacji, podczas których trudniej było się organizować. Grudzień '70 nie odbił się znaczącym echem wśród inteligencji i studentów, a potem zaczęły się nieco tłustsze pod względem materialnym i konsumpcyjnym lata gierkowskie, odczuwane też - przynajmniej początkowo - jako czas pewnego poluzowania ideologiczno-cenzuralnego i nieznanej za czasów Gomułki (nie mówiąc już o Bierucie) względnej swobody podróżowania, także na Zachód, która dla studentów i młodej inteligencji była dużą szansą nie tylko podreperowania budżetów (czarnorynkowy kurs walut zachodnich, a nawet waluty „bratniej” socjalistycznej Jugosławii, 
do której dość łatwo było legalnie wyjechać na tzw. wkładkę paszportową i bez wizy, bywał nawet 7-krotnie wyższy od oficjalnego - co dawało co obrotniejszym Polakom, w tym wielu studentom, okazję do pokaźnego zarobku), lecz i dostępu, np. w księgarniach polskich w Paryżu, do nieocenzurowanej literatury i, ogólnie mówiąc, pewnego udziału w tak nazywanym (w duchu uchwał Konferencji Helsińskiej z 1975 r.) „swobodnym przepływie idei i informacji”, wciąż bardzo ograniczonym w PRL. Wielu młodych ludzi, także „weteranów” Marca '68, zbyt ceniło sobie te nowe wówczas możliwości życiowe, by ryzykować ponowne narażanie się władzom i, co w ówczesnych warunkach było niemal oczywiste, „szlaban" na paszport. Cenne wydawało się także to, co wydawało się pod rządami Gierka „iść ku lepszemu” w Polsce - atmosfera społeczna nie była więc zbyt korzystna dla opozycyjności czy akcji protestacyjnych. Pewne ożywienie wniosła dopiero sprawa tzw. zjednoczenia organizacji młodzieżowych (którego elementem było połączenie ZSP z działającymi na wyższych uczelniach częściami ZMS i ZMW, zatem zniknięcie odrębnego i, przynajmniej formalnie, niekomunistycznego ZSP) w 1974 r., następnie zaś sprawa zmian w konstytucji i tzw. protestów konstytucyjnych w początkach 1976 r., wreszcie wydarzenia czerwcowe z 1976 r., powstanie KOR-u i rozwój zorganizowanej opozycji, w tym studenckiej, który utorował drogę ruchowi „Solidarności” i późniejszym przemianom politycznym i ustrojowym.

Ale to już temat na inną okazję. 